\title{
SUMBER STRES KERJA PERAWAT DI RUMAH SAKIT
}

\author{
Laela Hasanah ${ }^{1}$, Laili Rahayuwati ${ }^{2, *}$, Kurniawan Yudianto ${ }^{2}$ \\ ${ }^{1}$ Rumah Sakit Bandung, Indonesia \\ ${ }^{2}$ Departemen Keperawatan Dasar, \\ Fakultas Keperawatan Universitas Padjadjaran, Bandung, Indonesia \\ *)E-mail: lailira2002@yahoo.com
}

\begin{abstract}
ABSTRAK
Penelitian ini membahas tentang sumber stress kerja yang dialami oleh perawat yang bekerja di rumah sakit. Tujuan: penelitian ini untuk mengetahui sumber stres kerja perawat berdasarkan karakteristik perawat yang bekerja di Rumah Sakit. Metode: penelitian ini menggunakan metode deskriptif kuantitatif. Responden dalam penelitian ini adalah 239 perawat yang diambil dengan menggunakan teknik total populasi. Periode pengambilan data pada bulan Desember 2016. Instrumen yang digunakan adalah NIOSH Generic Job Stress Questionnaire, selanjutnya analisis univariat digunakan untuk melihat gambaran stresor kerja perawat berdasarkan karakteristik perawat. Hasil Penelitian: Berdasarkan analisis data terdapat 5 stresor kerja yaitu: harga diri, konflik peran, ketidakjelasan peran, konflik dalam kelompok, dan konflik antar kelompok. Kesimpulan: Data sumber stress yang didapatkan dari penelitian ini dapat digunakan untuk membuat sistem jenjang karir, memberikan pengakuan dan penghargaan atas prestasi yang dicapai perawat, memberikan kesempatan untuk berkembang kepada perawat, menyelenggarakan sistem rotasi yang terjadwal dan berkesinambungan.

Kata Kunci: Perawat, stresor kerja
\end{abstract}

\section{Nurses' Source of Stressor in The Hospital}

\section{ABSTRACT}

This study discusses the source of work stress experienced by nurses who work in hospital services Objective: The objective of this study was to determine the occupational stressors of nurses based on characteristics. Method: This research used descriptive quantitative methods. Respondents in this study were 239 nurses taken by total population. Data retrieval period in December 2016. This study utilized NIOSH Generic Job Stress Questionnaire. Univariate analysis used to describe the stressors of nurses based on the characteristics. Results: Based on the analysis of data from five work stressors that self-esteem, role conflict, role ambiguity, conflict in groups, conflict inter groups. Conclusion: The stressor data can be used to develop training of career system, the risk of job and career, recognize and reward the achievements for the nurses, provide the opportunity to develop, held a rotation system scheduled and continuously.

Keywords: nurse, occupational stressors

\section{LATAR BELAKANG}

Rumah Sakit Umum diklasifikasikan menjadi Rumah Sakit Umum kelas A, B, $C$, dan $D$ yang didasarkan pada unsur pelayanan yang diberikan, ketenagaan fisik, dan peralatannya. Rumah Sakit Bandung merupakan $\mathrm{RS}$ tipe $\mathrm{C}$ yang memiliki jumlah kapasitas rawat inap sebanyak 218 tempat tidur. Jumlah kunjungan pasien setiap tahunnya di poliklinik rawat jalan pada tahun
2015 sebanyak 138.541 pasien dan untuk rawat inap pada tahun 2015 sebanyak 18.749, rata-rata Bed Occupation Rate/BOR pada tahun 2015 adalah $70,89 \%$ dan pada bulan Januari-Juni 2016 adalah 71,65\%, serta jumlah tenaga sebanyak 241 perawat (Sistem Informasi Manajemen Rumah Sakit/ SIMRS Kota Bandung, 2016).

Stres merupakan suatu situasi yang dialami oleh manusia pada umumnya dan 
pegawai pada khususnya di dalam suatu organisasi atau pekerjaan. Penelitian oleh National Safety Council (2004) menyebutkan bahwa perawat menjadi salah satu pekerjaan yang dapat menyebabkan stres dibandingkan pekerjaan lain. Hal ini karena perawat mempunyai pekerjaan dengan sistem kerja shift, kewajiban untuk memberikan asuhan keperawatan secara holistik, beban kerja yang tinggi, serta konflik peran yang menjadikan seorang perawat rentan untuk mengalami stres.

Stres kerja perawat itu berbeda-beda setiap orang. National Safety Council (2004) menyebutkan bahwa stres merupakan persepsi terhadap situasi dan kondisi lingkungan. Persepsi ini akan berbeda berdasarkan karakteristik individu masingmasing seperti usia, jenis kelamin, pendidikan, status pernikahan, masa kerja dan unit kerja. Adapun stresor yang mengakibatkan stres kerja perawat menurut Gibson, dkk (2012) dan National Institute for Occupational Safety and Health/NIOSH (1999) yaitu tipe kepribadian, harga diri, konflik peran, ketidakjelasan peran, konflik dalam dan antar kelompok, beban kerja, tanggung jawab terhadap orang lain, dan dukungan sosial.

Dari hasil studi pendahuluan di Rumah Sakit Bandung dengan melakukan wawancara kepada Kepala Seksi Keperawatan didapatkan informasi bahwa pada saat ini sedang dalam upaya untuk meningkatkan status rumah sakit dari tipe $C$ ke tipe $B$. Adanya peningkatan sarana dan prasarana di rumah sakit seperti penambahan ruang rawat inap, penambahan kapasitas tempat tidur, penambahan dokter-dokter spesialis dan lain-lain membuat tingkat kesulitan dan beban kerja hampir diseluruh ruangan semakin meningkat karena banyak kasuskasus baru yang lebih rumit yang ditangani di Rumah Sakit Bandung.
Sumber stres kerja perawat di Rumah Sakit Bandung belum dapat diketahui, meskipun dari penelitian sebelumnya diketahui secara umum perawat Rumah Sakit Bandung mengalami tingkat stres kerja sedang. Stres tingkat sedang bila tidak ditangani secara serius maka lambat laun akan meningkat menjadi stres tingkat tinggi dan hal ini tentu saja dapat membahayakan kelangsungan rumah sakit dengan adanya penurunan produktivitas perawat sehingga menurunkan kinerja.

Berdasarkan uraian latar belakang, penanganan stress kerja perawat di Rumah Sakit Bandung belum dapat dilakukan secara maksimal oleh pihak manajemen rumah sakit. Oleh karena itu perlu dilakukan penelitian tentang stressor kerja perawat berdasarkan karakteristik perawat, karena karakteristik perawat memengaruhi persepsi terhadap stressor kerja yang dialami oleh perawat, sehingga respons setiap perawat akan berbeda.

\section{METODE}

Rancangan penelitian ini adalah deskriptif kuantitatif, bertujuan mendapatkan gambaran mengenai stressor kerja perawat berdasarkan karakteristik perawat di Rumah Sakit Bandung. Variabel penelitian adalah stressor kerja perawat dan karakteristik perawat di Rumah Sakit Bandung. Untuk stressor kerja perawat terdiri dari harga diri, konflik peran, ketidakjelasan peran, adanya konflik dalam dan antar kelompok. Sedangkan untuk karakteristik perawat terdiri dari usia, jenis kelamin, pendidikan, status pernikahan, masa kerja dan unit kerja.

Populasi dalam penelitian ini adalah semua perawat yang aktif bekerja di IGD (Instalasi Gawat Darurat), ICU (Intensive Care Unit) PICU/NICU (Pediatric Intensive Care Unit/Neonatus Intensive Care Unit), ruangan rawat inap, ruang Hemodialiasis, 
Instalasi Bedah Sentral (IBS) dan rawat jalan Rumah Sakit Umum Daerah Kota Bandung yang berjumlah 241 orang. Teknik pengambilan sampel pada total populasi dilakukan pada sejumlah 239 perawat (dengan ketidakhadiran 2 orang perawat karena cuti). Periode pengambilan data pada bulan Desember 2016.

Jenis data yang digunakan pada penelitian ini adalah data primer yang diambil dari kuesioner. Kuesioner dalam penelitian terdiri dari dua bagian yaitu karakteristik perawat dan stresor kerja perawat. Kuesioner ini berisikan pertanyaan-pertanyaan yang diberikan ke seluruh perawat yang berada di IGD, ICU, PICU/NICU, ruangan rawat inap, ruang Hemodialisa, Instalasi Bedah Sentral (IBS) dan rawat jalan.

Instrumen yang digunakan adalah NIOSH Generic Job Stress Questionnaire. Indikator berupa pernyataan yang digunakan adalah: harga diri, konflik peran, ketidakjelasaan peran, konflik dalam kelompok, konflik antar kelompok, total pertanyaan 40 item. Tidak disebutkan jumlah responden dalam uji validitas dan realibilitas, namun dalam original instrument hanya disebutkan bahwa instrumen ini telah divalidasi oleh beberapa inventor NIOSH Generic Job Stress Questionnaire dengan nilai validitas 0,68-0,91 dan Short Rating Scale dengan reliabilitas sebesar 0,53 di Indonesia (Somantri, 2006; Yasuaki, Chiba \& Eiji, 2012).

Instrumen ini menggunakan skor 1-5 pada skala Likert (Sangat Tidak Setuju, Setuju, Netral, Tidak Setuju, Sangat Tidak Setuju) pada indikator variabel stresor kerja yaitu harga diri, konflik dalam kelompok, konflik antar kelompok. Selanjutnya, menggunakan skala Likert dengan skor 1-7 (Sangat Setuju, Setuju, Netral, Ragu-ragu, Tidak menjawab, Tidak Setuju, Sangat
Tidak Setuju) pada indikator stressor kerja, konflik peran dan ketidakjelasan peran. Pada pernyataan positif rentang skor adalah 5-1 atau 7-1, sedang untuk pernyataan negatif rentang skor 1-5 atau 1-7. Penilaian dilakukan dengan menjumlahkan skor yang diperoleh pada masing-masing komponen stressor (harga diri, konflik peran, ketidakjelasan peran, konflik dalam kelompok, konflik antar kelompok).

Analisis data univariat dilakukan terhadap data dari variabel stressor kerja dengan masing-masing indikator stressor kerja berdasarkan karakteritik individu. Pengolahan data untuk mendapatkan gambaran stresor kerja perawat berdasarkan karakteristik perawat dilakukan dengan cara menghitung total skor dalam skala Likert dan dicari nilai mean untuk harga diri, konflik peran, ketidakjelasan peran, konflik dalam kelompok, konflik antar kelompok, beban kerja, tanggung jawab terhadap orang lain dan dukungan sosial.

Semakin tinggi skor indikator stresor kerja (konflik peran, ketidakjelasan peran, konflik dalam kelompok, konflik antar kelompok) maka semakin kecenderungan untuk menjadi stressor kerja. Sedangkan semakin rendah skor indikator stressor kerja (harga diri) maka semakin kecenderungan untuk menjadi stressor kerja. Pengelompokan data rendah dan tinggi pada beberapa variabel berdasarkan pada nilai median. Ijin etik penelitian didapatkan dari Komis Etik Penelitian Kesehatan Fakultas Kedokteran Unpad.

\section{HASIL}

Data karakteristik responden dapat dilihat pada tabel 1. 
Tabel 1. Distribusi Karakteristik Perawat Rumah Sakit Bandung ( $n=239)$

\begin{tabular}{|c|c|c|c|}
\hline No & Variabel & f & $\%$ \\
\hline \multicolumn{4}{|c|}{ 1. Jenis Kelamin } \\
\hline & Laki-laki & 67 & 28 \\
\hline & Perempuan & 172 & 72 \\
\hline \multicolumn{4}{|c|}{ 2. Usia } \\
\hline & $20-40$ & 227 & 95 \\
\hline & $41-55$ & 12 & 5 \\
\hline \multirow[t]{3}{*}{3.} & Status Pernikahan & & \\
\hline & Menikah & 173 & 72,4 \\
\hline & Belum Menikah & 66 & 27,6 \\
\hline \multicolumn{4}{|c|}{ 4. Masa Kerja } \\
\hline & $<2$ tahun & 64 & 26,8 \\
\hline & 2-10 tahun & 126 & 52,7 \\
\hline & $>10$ tahun & 49 & 20,5 \\
\hline \multicolumn{4}{|c|}{ 5. Tingkat Pendidikan } \\
\hline & SPK & 2 & 0,9 \\
\hline & D3 Keperawatan & 192 & 80,3 \\
\hline & S1 Ners & 45 & 18,8 \\
\hline \multicolumn{4}{|c|}{ 6. Unit Kerja } \\
\hline & IGD & 28 & 11,7 \\
\hline & $\mathrm{ICU}$ & 19 & 7,9 \\
\hline & PICU/NICU & 20 & 8,4 \\
\hline & Rawat Inap & 118 & 49,4 \\
\hline & Hemodialisa & 9 & 3,8 \\
\hline & Instalasi Bedah Sentral & 30 & 12,5 \\
\hline & Rawat Jalan & 15 & 6,3 \\
\hline
\end{tabular}

Berdasarkan tabel 1 dapat dilihat bahwa karakteristik perawat Rumah Sakit Bandung sebagian besar perawat berjenis kelamin perempuan sebanyak 172 orang $(72 \%)$, untuk usia sebagian besar berada pada rentang usia 20-40 tahun sebanyak 227 orang (95\%). Pengelompokan usia berdasar kategori usia produktif menurut UU Tenaga Kerja no 13 tahun 2013. Status pernikahan perawat sebagian perawat berstatus menikah sebanyak 173 orang $(72,4 \%)$. Adapun pengelompokan masa kerja berdasar Global Work Force (2012), masa kerja perawat sebagian besar berada pada kisaran masa kerja 2-10 tahun sebanyak 126 orang (52,7\%). Karakteristik perawat berdasarkan tingkat pendidikan menunjukkan sebagian besar perawat memiliki latar belakang DIII Keperawatan sebanyak 192 orang (80,3\%). Karakteristik unit kerja, perawat paling banyak berada pada unit kerja rawat inap sebanyak 118 $(49,4)$. 
Tabel 2. Distribusi Stressor Kerja Perawat Rumah Sakit Bandung ( $n=239)$

\begin{tabular}{lccccc}
\hline \multirow{2}{*}{ Stresor Kerja } & \multicolumn{2}{c}{ Tinggi } & \multicolumn{2}{c}{ Rendah } & \multirow{2}{*}{ Total } \\
\cline { 2 - 5 } & $\mathbf{f}$ & \% & $\mathbf{f}$ & $\%$ & \\
\hline Harga Diri & 126 & 52,7 & 113 & 47,3 & 35,44 \\
Konflik Peran & 129 & 54 & 110 & 46 & 31,23 \\
Ketidakjelasan Peran & 157 & 65,7 & 82 & 34,3 & 17,00 \\
Konflik Dalam Kelompok & 101 & 42,3 & 138 & 57,7 & 18,07 \\
Konflik Antar Kelompok & 106 & 44,4 & 133 & 55,6 & 18,16 \\
\hline
\end{tabular}

Berdasarkan tabel 2 dapat dilihat bahwa sebagian besar perawat Rumah Sakit Bandung mempunyai harga diri tinggi sebanyak 126 orang $(52,7 \%)$, konflik peran tinggi sebanyak 129 orang (54\%), ketidakjelasan peran sebanyak 157 orang
$(65,7 \%)$, konflik dalam kelompok rendah sebanyak 101 orang (42,3\%), konflik antar kelompok rendah sebanyak 133 orang $(55,6 \%)$. Stresor kerja harga diri berdasarkan karakteristik perawat dapat dilihat pada tabel 3.

Tabel 3. Distribusi Stressor Kerja Harga Diri Berdasarkan Karakteristik Perawat Rumah Sakit Bandung ( $n=239)$

\begin{tabular}{llcccc}
\hline \multirow{2}{*}{ Karakteristik Perawat } & \multicolumn{4}{c}{ Harga Diri } \\
\cline { 3 - 6 } & & \multicolumn{2}{c}{ Tinggi } & \multicolumn{3}{c}{ Rendah } \\
\cline { 2 - 5 } Jenis Kelamin & Laki-laki & $\mathbf{f}$ & $\%$ & $\mathbf{f}$ & $\%$ \\
& Perempuan & 40 & 59,7 & 27 & 40,3 \\
& Usia & 86 & 50 & 86 & 50 \\
\hline Status & 20-40 tahun & 120 & 52,9 & 107 & 47,1 \\
Pernikahan & Menikah & 6 & 50 & 6 & 50 \\
\hline Masa Kerja & Belum Menikah & 97 & 56,1 & 76 & 43,9 \\
& $<2$ tahun & 28 & 43,9 & 37 & 56,1 \\
\hline Pendidikan & $2-10$ tahun & 26 & 40,6 & 38 & 59,4 \\
& $>10$ tahun & 70 & 55,6 & 56 & 44,4 \\
& SPK & 30 & 61,2 & 19 & 38,8 \\
\hline Unit Kerja & DIII & 1 & 50 & 1 & 50 \\
& S1 Ners & 104 & 54,2 & 88 & 45,8 \\
& IGD & 21 & 46,7 & 24 & 53,3 \\
\hline & ICU & 14 & 50 & 14 & 50 \\
& PICU/NICU & 11 & 57,9 & 8 & 42,1 \\
& Rawat Inap & 13 & 65 & 7 & 35 \\
& Hemodialisa & 52 & 44,1 & 66 & 55,9 \\
& Instalasi Bedah Sentral & 8 & 88,9 & 1 & 11,1 \\
& Rawat Jalan & 19 & 63,3 & 11 & 36,7 \\
& & 9 & 60 & 6 & 40 \\
\hline
\end{tabular}


Dari tabel 3 didapatkan hasil harga diri diperoleh pada laki-laki sebanyak 40 orang $(59,7 \%)$ dan sebagian besar harga diri rendah pada perempuan sebanyak 86 orang (50\%), berdasarkan usia 20-40 tahun mempunyai harga diri tinggi sebanyak 120 orang $(52,9 \%)$ dan harga diri rendah pada usia 41-60 tahun sebanyak 6 orang (50\%), berdasarkan status pernikahan, harga diri tinggi pada status pernikahan menikah 97 orang $(56,1 \%)$ dan sebagian besar harga diri rendah pada status belum menikah sebanyak 37 orang $(56,1 \%)$, berdasarkan masa kerja, sebagian besar perawat mempunyai harga diri tinggi pada masa kerja $>10$ tahun sebanyak 30 orang $(61,2 \%)$ dan sebagian besar harga diri rendah pada masa kerja $<2$ tahun sebanyak 38 orang $(59,4 \%)$. Berdasarkan pendidikan sebagian besar perawat mempunyai harga diri tinggi pada pendidikan D III keperawatan yaitu sebanyak 104 orang $(54,2 \%)$ dan sebagian besar mempunyai harga diri rendah pada S1 Ners sebanyak 24 orang $(53,3 \%)$. Berdasarkan unit kerja, perawat Hemodialisa sebagian besar mempunyai harga diri tinggi sebanyak 8 orang $(88,9 \%)$ dan separuh lebih responden harga diri rendah pada unit kerja rawat inap sebanyak 66 orang $(55,9 \%)$.

Stresor kerja konflik peran berdasarkan karakteristik perawat pada tabel 4.

Tabel 4. Distribusi Stresor Kerja Konflik Peran Berdasarkan Karakteristik Perawat Rumah Sakit Bandung ( $n=239)$

\begin{tabular}{|c|c|c|c|c|c|}
\hline & & \multicolumn{4}{|c|}{ Konflik Peran } \\
\hline \multicolumn{2}{|c|}{ Karakteristik Perawat } & \multicolumn{2}{|c|}{ Tinggi } & \multicolumn{2}{|c|}{ Rendah } \\
\hline & & f & $\%$ & f & $\%$ \\
\hline Jenis & Laki-laki & 39 & 58,2 & 28 & 41,8 \\
\hline Kelamin & Perempuan & 90 & 52,3 & 82 & 47,7 \\
\hline \multirow[t]{2}{*}{ Usia } & 20-40 tahun & 123 & 54,2 & 104 & 45,8 \\
\hline & 41-60 tahun & 6 & 50 & 6 & 50 \\
\hline Status & Menikah & 86 & 49,7 & 87 & 50,3 \\
\hline Pernikahan & Belum Menikah & 43 & 65,2 & 23 & 34,8 \\
\hline \multirow[t]{3}{*}{ Masa Kerja } & $<2$ tahun & 34 & 53,1 & 30 & 46,9 \\
\hline & 2-10 tahun & 71 & 56,3 & 55 & 43,7 \\
\hline & $>10$ tahun & 24 & 49 & 25 & 51 \\
\hline \multirow[t]{3}{*}{ Pendidikan } & SPK & 1 & 50 & 1 & 50 \\
\hline & DIII & 98 & 51 & 94 & 49 \\
\hline & S1 Ners & 30 & 66,7 & 15 & 33,3 \\
\hline \multirow[t]{7}{*}{ Unit Kerja } & IGD & 17 & 60,7 & 11 & 39,3 \\
\hline & $\mathrm{ICU}$ & 12 & 63,2 & 7 & 36,8 \\
\hline & PICU/NICU & 8 & 40 & 12 & 60 \\
\hline & Rawat Inap & 68 & 57,6 & 50 & 42,4 \\
\hline & Hemodialisa & 5 & 55,6 & 4 & 44,4 \\
\hline & Instalasi Bedah Sentral & 13 & 43,3 & 17 & 56,7 \\
\hline & Rawat Jalan & 16 & 40 & 9 & 60 \\
\hline
\end{tabular}


Dari tabel 4 didapatkan hasil konflik peran tinggi pada jenis kelamin laki-laki sebanyak $39(58,2 \%)$, usia 20-40 tahun sebanyak 123 orang $(54,2 \%)$, status pernikahan belum menikah sebanyak 43 orang $(65,2 \%)$, masa kerja 2-10 tahun sebanyak 71 orang
$(56,3 \%)$, pendidikan S1 Ners sebanyak 30 orang $(66,7 \%)$ dan unit kerja ICU 12 orang $(63,2 \%)$. Stresor kerja ketidakjelasan peran berdasarkan karakteristik perawat pada tabel 5.

Tabel 5. Distribusi Stresor Kerja Ketidakjelasan Peran Berdasarkan Karakteristik Perawat Rumah Sakit Bandung $(n=239)$

\begin{tabular}{llcccc}
\hline \multirow{2}{*}{ Karakteristik Perawat } & \multicolumn{3}{c}{ Ketidakjelasan Peran } \\
\cline { 3 - 6 } & & \multicolumn{2}{c}{ Tinggi } & \multicolumn{2}{c}{ Rendah } \\
\cline { 2 - 5 } Jenis Kelamin & Laki-laki & $\mathbf{f}$ & $\%$ & $\mathbf{f}$ & $\%$ \\
& Perempuan & 41 & 61,2 & 26 & 38,8 \\
& 20-40 tahun & 116 & 67,4 & 56 & 32,6 \\
\hline \multirow{2}{*}{ Usia } & 41-60 tahun & 153 & 67,4 & 74 & 32,6 \\
Pernikahan & Menikah & 4 & 33,3 & 8 & 66,7 \\
\hline \multirow{3}{*}{ Masa Kerja } & Belum Menikah & 108 & 62,4 & 65 & 37,6 \\
& 2-10 tahun & 49 & 74,2 & 17 & 25,8 \\
\hline \multirow{3}{*}{ Pendidikan } & $>10$ tahun & 42 & 65,6 & 22 & 34,4 \\
& SPK & 87 & 69 & 39 & 31 \\
& DIII & 28 & 57,1 & 21 & 42,9 \\
\hline \multirow{3}{*}{ Unit Kerja } & S1 Ners & 1 & 50 & 1 & 50 \\
& IGD & 128 & 66,7 & 64 & 33,3 \\
& ICU & 28 & 62,2 & 17 & 37,8 \\
\hline & PICU/NICU & 22 & 78,6 & 6 & 21,4 \\
& Rawat Inap & 11 & 57,9 & 8 & 42,1 \\
& Hemodialisa & 7 & 35 & 13 & 65 \\
& Instalasi Bedah Sentral & 17 & 56,7 & 13 & 43,3 \\
& Rawat Jalan & 9 & 60 & 6 & 40 \\
\hline
\end{tabular}

Dari tabel 5 didapatkan hasil bahwa stresor kerja ketidakjelasan peran berdasarkan karakteristik diperoleh bahwa sebagian besar perawat mempunyai ketidakjelasan peran tinggi pada jenis kelamin perempuan sebanyak $116(67,4 \%)$, usia 20-40 tahun sebanyak 153 orang $(67,4 \%)$, status pernikahan belum menikah sebanyak 49 orang $(74,2 \%)$, masa kerja $2-10$ tahun sebanyak 87 orang (69\%), pendidikan D III sebanyak 128 orang $(66,7 \%)$ dan unit kerja IGD 22 orang $(78,6 \%)$. Stresor kerja konflik dalam kelompok berdasarkan karakteristik perawat bisa dilihat dalam tabel 6 . 
Tabel 6. Distribusi Stresor Kerja Konflik Dalam Kelompok Berdasarkan Karakteristik Perawat Rumah Sakit Bandung $(n=239)$

\begin{tabular}{|c|c|c|c|c|c|}
\hline & & \multicolumn{4}{|c|}{ Konflik Dalam Kelompok } \\
\hline \multicolumn{2}{|c|}{ Karakteristik Perawat } & \multicolumn{2}{|c|}{ Tinggi } & \multicolumn{2}{|c|}{ Rendah } \\
\hline & & f & $\%$ & f & $\%$ \\
\hline Jenis & Laki-laki & 25 & 37,3 & 42 & 62,7 \\
\hline Kelamin & Perempuan & 76 & 44,2 & 96 & 55,8 \\
\hline \multirow[t]{2}{*}{ Usia } & 20-40 tahun & 97 & 42,7 & 130 & 57,3 \\
\hline & 41-60 tahun & 4 & 33,3 & 8 & 66,7 \\
\hline Status & Menikah & 67 & 38,7 & 106 & 61,3 \\
\hline Pernikahan & Belum Menikah & 34 & 51,5 & 32 & 48,5 \\
\hline \multirow[t]{3}{*}{ Masa Kerja } & $<2$ tahun & 33 & 51,6 & 31 & 48,4 \\
\hline & 2-10 tahun & 55 & 43,7 & 71 & 56,3 \\
\hline & $>10$ tahun & 13 & 26,5 & 36 & 73,5 \\
\hline \multirow[t]{3}{*}{ Pendidikan } & SPK & 1 & 50 & 1 & 50 \\
\hline & DIII & 83 & 43,2 & 109 & 56,8 \\
\hline & S1 Ners & 17 & 37,8 & 28 & 62,2 \\
\hline \multirow[t]{7}{*}{ Unit Kerja } & IGD & 13 & 46,4 & 15 & 53,6 \\
\hline & ICU & 9 & 47,4 & 10 & 52,6 \\
\hline & PICU/NICU & 9 & 45 & 11 & 55 \\
\hline & Rawat Inap & 45 & 38,1 & 73 & 61,9 \\
\hline & Hemodialisa & 7 & 77,8 & 2 & 22,2 \\
\hline & Instalasi Bedah Sentral & 14 & 46,7 & 16 & 53,3 \\
\hline & Rawat Jalan & 4 & 26,7 & 11 & 73,3 \\
\hline
\end{tabular}

Dari Tabel 6 didapatkan hasil konflik dalam kelompok sebagian besar pada status pernikahan belum menikah sebanyak 34 orang $(51,5 \%)$, masa kerja $<2$ tahun sebanyak 33 orang $(51,6 \%)$ dan pada unit kerja Hemodialisis sebanyak 7 orang $(77,8 \%)$. Stresor kerja konflik antar kelompok berdasarkan karakteristik perawat pada tabel 7.

Dari tabel 7 konflik antar kelompok pada sebagian besar status pernikahan belum menikah sebanyak 38 orang $(57,6 \%)$, pendidikan S1 Ners sebanyak 24 orang
$(53,3 \%)$ dan pada unit kerja IGD 18 orang $(64,3 \%)$.

\section{DISKUSI}

Jumlah mayoritas perawat (172) berjenis kelamin perempuan, dapat memberikan efek positif dan negatif. Disatu sisi dengan sebagian besar perawat berjenis kelamin perempuan dapat menjadikan kualitas asuhan keperawatan menjadi lebih baik dengan karakter perempuan yang memiliki sifat caring yang lebih tinggi dibandingkan laki-laki (Porter, 1992; Triwijayanti, 
Tabel 7. Distribusi Stresor Kerja Konflik Antar Kelompok Berdasarkan Karakteristik Perawat Rumah Sakit Bandung ( $n=239)$

\begin{tabular}{|c|c|c|c|c|c|}
\hline & & \multicolumn{4}{|c|}{ Konflik Antar Kelompok } \\
\hline \multicolumn{2}{|c|}{ Karakteristik Perawat } & \multicolumn{2}{|c|}{ Tinggi } & \multicolumn{2}{|c|}{ Rendah } \\
\hline & & $f$ & $\%$ & $f$ & $\%$ \\
\hline Jenis & Laki-laki & 30 & 44,8 & 37 & 55,2 \\
\hline Kelamin & Perempuan & 76 & 44,2 & 96 & 55,8 \\
\hline \multirow[t]{2}{*}{ Usia } & 20-40 tahun & 102 & 44,9 & 125 & 55,1 \\
\hline & 41-60 tahun & 4 & 33,3 & 8 & 66,7 \\
\hline Status & Menikah & 68 & 39,3 & 105 & 60,7 \\
\hline Pernikahan & Belum Menikah & 38 & 57,6 & 28 & 42,4 \\
\hline \multirow[t]{3}{*}{ Masa Kerja } & $<2$ tahun & 30 & 46,9 & 34 & 53,1 \\
\hline & 2-10 tahun & 62 & 49,2 & 64 & 50,6 \\
\hline & $>10$ tahun & 14 & 28,6 & 35 & 71,4 \\
\hline \multirow[t]{3}{*}{ Pendidikan } & SPK & 1 & 50 & 1 & 50 \\
\hline & DIII & 81 & 42,2 & 111 & 57,8 \\
\hline & S1 Ners & 24 & 53,3 & 21 & 46,7 \\
\hline \multirow[t]{7}{*}{ Unit Kerja } & IGD & 18 & 64,3 & 10 & 35,7 \\
\hline & ICU & 12 & 63,2 & 7 & 36,8 \\
\hline & $\mathrm{PICU} / \mathrm{NICU}$ & 6 & 30 & 14 & 70 \\
\hline & Rawat Inap & 49 & 41,5 & 69 & 58,5 \\
\hline & Hemodialisa & 3 & 33,3 & 6 & 66,7 \\
\hline & Instalasi Bedah Sentral & 12 & 40 & 18 & 60 \\
\hline & Rawat Jalan & 6 & 40 & 9 & 60 \\
\hline
\end{tabular}

Dwiantoro, \& Warsito 2016). Di sisi lain, jumlah perawat perempuan yang lebih banyak bisa menimbulkan stresor kerja tersendiri yang akan berpengaruh terhadap kinerja dan kondusifitas rumah sakit. Lee \& Wang (2002) menemukan perbedaan yang signifikan antara laki-laki dan perempuan terkait hal efek dari stres kerja, perempuan lebih cepat mengalami masalah seperti gangguan mental, kecemasan dan penyakit psikosomatik sedangkan laki-laki lebih cepat menderita penyakit jantung karena pekerjaan termasuk stres.
Dalam sebuah penelitian didapatkan bahwa perawat perempuan memiliki stres kerja tinggi karena dipengaruhi oleh kondisi pekerjaan, hubungan dengan teman kerja, konflik peran, struktur organisasi pekerjaan, iklim pekerjaan, pekerjaan rumah serta perkembangan karir (Tankha, 2006).

Berdasarkan hasil penelitian diketahui bahwa sebagian besar responden yaitu 227 orang $(95 \%)$ berada pada rentang usia dewasa awal. Pada rentang ini merupakan usia produktif untuk bisa menunjukkan etos kerja yang optimal dibandingkan dengan 
rentang usia di atasnya. Pada rentang usia ini perawat cenderung memiliki fisik yang kuat, dinamis dan kreatif sehingga lebih mudah untuk mencapai kinerja secara maksimal. Hal ini sesuai dengan pernyataan Mangkunegara (2000) yang menyatakan bahwa karyawan atau pekerja muda memiliki sikap kreatif dan memiliki keinginan untuk maju, rasa ingin tahu yang tinggi, energik, terbuka menerima pendapat, memiliki inisiatif tinggi, serta pemikiran yang luas dan terarah yang menunjang pencapaian kinerja yang optimal.

Sebanyak 173 orang (72.4\%) perawat di RSUD Kota Bandung berstatus sudah menikah. Status pernikahan seseorang dapat memberikan efek berbeda terhadap tingkat stres kerja perawat di RSUD Bandung. Status pernikahan dapat memberikan efek positif karena seseorang yang sudah menikah memiliki sumber dukungan dari keluarga dan pasangannya. Namun di sisi lain status pernikahan dapat menyebabkan stres kerja perawat lebih tinggi hal ini terjadi karena mayoritas perawat ialah perempuan dimana memiliki banyak peran diantaranya sebagai istri, ibu, pekerja dan mengurus rumah tangga.

Sejalan dengan pendapat di atas Milutinovic, dkk (2012) menyatakan bahwa peran ganda yang dimiliki perempuan menyebabkan tingkat stres kerja perawat perempuan yang sudah menikah cenderung lebih tinggi. Namun lain halnya dengan hasil penelitian Ismafiaty (2009) yang menyatakan bahwa status pernikahan belum tentu memengaruhi tingkat stres kerja. Hal ini tergantung dari bagaimana cara individu menghadapi masalah. Hal ini diperkuat oleh Prihatini (2007) yang menyatakan bahwa tidak ada hubungan yang bermakna antara status pernikahan dengan stres kerja perawat karena seseorang menikah atau belum menikah dalam kehidupan tidak mempengaruhi stress pekerjaan, dalam manajemen stres tersebut tergantung dari sifat individu masing-masing sama halnya dengan perawat bahwa pemicu stress belum tentu dari status perkawinan, namun dapat dari beban kerja, lingkungan kerja, dan tuntutan pekerjaan.

Sebagian besar responden memiliki masa kerja antara 2-10 tahun yaitu sebanyak 126 orang (52.7\%). Masa kerja antara 2-10 tahun merupakan tahap lanjutan (advancement stage), tahap dimana berorientasi pada prestasi kerja tinggi, dimana orang-orang berfokus pada peningkatan kompetensi mereka (McElroy, Morrow, \& Wardlow, 1999). Hal ini menjadi suatu energi positif bagi RSUD Kota Bandung karena masa kerja yang lebih lama erat kaitannya dengan pengalaman dan pemahaman mengenai job description yang lebih baik, dimana akan membantu perawat dalam mengatasi masalah (stresor) yang ada dalam upaya pencegahan stress.

Dari hasil penelitian didapatkan data bahwa sebagian besar responden berada pada tingkat pendidikan D3 Keperawatan 192 orang (80.3\%). Tingkat pendidikan berpengaruh terhadap daya kritik dan daya nalar sehingga individu semakin mampu untuk menyelesaikan masalah yang dihadapi, mengatakan tekanan atau beban kerja yang dihadapinya, mampu menyesuaikan diri terhadap pekerjaanya dan pada akhirnya mampu mengontrol stres yang dialaminya. Kurangnya pengetahuan, kurangnya pengalaman dan kurangnya tingkat pendidikan yang lebih tinggi berkontribusi untuk terjadinya stres kerja pada perawat (Rivera-Torres, Araque-Padilla \& Montero-Simó, 2013).

Semakin tinggi pendidikan seseorang maka semakin banyak pengetahuan yang didapatkan sehingga mereka akan lebih mampu mengatasi stres yang terjadi dalam dirinya dibandingkan dengan mereka yang berpendidikan lebih rendah. Kurangnya 
pengetahuan dalam menghadapi masalah di tempat kerja dapat memicu terjadinya stres kerja menyebabkan kinerja yang rendah, komunikasi yang tidak lancar, keputusan yang jelek, kreativitas, dan inovasi kurang sehingga bergulat dengan tugas-tugas yang tidak produktif. Hal ini juga yang diungkapkan oleh Pramadi dan Lasmono (2003) bahwa seseorang yang memiliki tingkat pendidikan tinggi memiliki pola pikir berani dalam mengambil sikap untuk mengatasi masalah dan tidak menunda-nunda, karena kemungkinan itu akan menambah beban dalam berpikir.

Prihatini (2007) menyatakan bahwa perawat yang bekerja lebih dari 5 tahun telah mampu menyesuaikan diri dengan lingkungan tempat ia bekerja. Hal inilah yang membuat perawat tersebut terbiasa dengan kondisi pekerjaan yang harus dilakukan sehari-hari pada tempat dan waktu yang sama sehingga mereka cenderung tidak mengalami stres daripada perawat yang belum lama bekerja. Sejalan dengan pendapat Retnoningsih (2000) didapatkan bahwa perilaku perawat dalam merawat pasien dipengaruhi oleh masa kerja perawat. Hal ini karena semakin lama perawat bekerja maka kemampuan dan pengalaman dalam merawat juga akan semakin baik.

Dari hasil penelitian diketahui bahwa secara keseluruhan sebagian besar responden memiliki harga diri yang tinggi sebanyak 126 orang $(52,7 \%)$. Harga diri adalah persepsi individu terhadap kemampuan dirinya, bagaimana dirinya serta keberhasilan dirinya. Menurut Nurvia dan Safitri (2009), kelompok individu yang memiliki harga diri tinggi dicirikan dengan individu yang cenderung aktif, ekspresif, berhasil dalam bidang akademik dan sosial, mempunyai dorongan untuk mengutarakan pendapatnya, tidak peka terhadap kritik, mudah menolak, jarang tergantung pada perasaaan cemas dan mempunyai pandangan positif terhadap orang lain.

Jumlah perawat yang memiliki harga diri rendah tidak terlalu berbeda jauh dengan yang memiliki harga diri tinggi yaitu sebanyak 113 orang $(47,3 \%)$. Menurut Nurvia \& Safitri (2009) kelompok individu dengan harga diri rendah bercirikan dengan individu yang diliputi dengan kekhawatiran tentang interaksi sosial dan tidak yakin akan keberhasilannya. Orang yang dengan harga diri rendah digambarkan mempunyai sifat-sifat depresif, terlalu lemah untuk melawan kekurangan diri, disibukkan oleh persoalan pribadi, cenderung terisolir dan peka terhadap kritik. Dari ciri tersebut seseorang dengan harga diri rendah akan kecenderungan akan terkena stress dan hal ini sejalan dengan penelitian yang dilakukan oleh Lee, Joo, \& Choi (2013) yang melakukan penelitian terhadap perawat di Korea didapatkan hasil bahwa harga diri yang rendah akan menyebabkan stres kerja tinggi.

Harga diri seorang perawat akan terbentuk melalui proses berpikir, nilai-nilai keinginan, tujuan dan pada akhirnya nanti akan menjadi cermin dari kinerja seseorang (Setyawan, 2016). Lebih lanjut lagi harga diri merupakan kunci terpenting dalam pembentukan perilaku seseorang pekerja, karena berpengaruh pada proses berpikir, tingkat emosi, keputusan-keputusan yang diambil bahkan berpengaruh pada nilai-nilai dan tujuan hidupnya serta memungkinkan seorang pekerja untuk mampu menikmati pekerjaannya (Setyawan, 2016).

Stresor kerja konflik peran secara keseluruhan didapatkan hasil perawat memiliki konflik perang yang tinggi sebanyak 129 orang (54\%). Menurut Indrawan (2009) konflik peran timbul jika seorang tenaga kerja mengalami adanya pertentangan antara tugas-tugas yang harus ia lakukan dan antara tanggung jawab yang ia miliki, tugas-tugas yang harus ia lakukan yang 
menurut pandangannya bukan merupakan bagian dari pekerjaannya, tuntutan-tuntutan yang bertentangan dari atasan, rekan, bawahannya atau orang lain yang dinilai penting bagi dirinya, pertentangan dengan nilai-nilai dan keyakinan pribadinya sewaktu melakukan tugas pekerjaan.

Konflik peran yang tinggi mempunyai konsekuensi atau dampak terhadap berhasil tidaknya organisasi karena konflik peran yang tinggi akan menjadi sumber stress dan tingkat kepuasan kerja dari seorang pekerja dimana tingkat kepuasan ini berpengaruh positif terhadap komitmen pada organisasi

Ketidakjelasan peran dalam penelitian ini didapatkan hasil bahwa perawat mengalami ketidakjelasan peran yang tinggi sebanyak 157 orang $(65,7 \%)$. Ketidakjelasan peran merujuk kepada kurangnya kejelasan informasi tentang tugas, kewajiban dan pertanggungjawaban yang melekat pada sebuah pekerjaan (Mulyono, 2010). Dengan demikian individu akan merasakan tekanan ketika menghadapi ketidakpastian bagaimana ia harus berperilaku sebagai bagian dari tuntutan perannya. Penulis mengilustrasikan ketidakjelasan peran yang dialami oleh perawat muncul ketika perawat harus mengerjakan tugas-tugas yang bukan bagian dari tugasnya tapi hal itu sudah menjadi suatu kebiasaan yang selalu dikerjakan oleh perawat.

Konflik dalam kelompok berdasarkan hasil penelitian didapatkan hasil sebagian besar konflik dalam kelompok rendah yaitu sebanyak 138 orang $(57,7 \%)$, maka kecenderungan sebagian besar perawat mempunyai persepsi bahwa konflik dalam kelompok tidak dijadikan sebagai stresor dalam bekerja. Konflik dalam kelompok berhubungan dengan cara individu menanggapi tekanan untuk keseragaman yang dipaksakan oleh kelompok kerja mereka (Lumintang, 2015). Konflik ini sering terjadi karena seseorang secara terus menerus berinteraksi dengan orang lain, sehingga ditemukan perbedaan-perbedaan. Konflik yang terjadi dapat menyebabkan komunikasi menjadi tidak baik, kepuasan kerja rendah dan lebih meningkatkan terjadinya stres kerja (Gibson, dkk, 2012).

Konflik antar kelompok berdasarkan hasil penelitian didapatkan hasil sebagian besar mempunyai konflik antar kelompok rendah sebanyak 133 orang $(55,6 \%)$. Konflik antar kelompok terjadi antara dua atau lebih, kelompok, departemen atau organisasi. Sumber konflik jenis ini adalah hambatan dalam mencapai kekuasaan dan otoritas (kualitas jasa pelayanan) serta keterbatasan prasarana. Konflik antar kelompok mempunyai ciri kegagalan untuk berkomunikasi, ketidak percayan dan fokus pada kepentingan diri sendiri (Borkowski, 2015).

Harga diri adalah persepsi individu terhadap kemampuan dirinya, bagaimana dirinya serta keberhasilan dirinya (Fennel, 2016). Dari hasil penelitian didapatkan bahwa secara keseluruhan perawat RSUD Kota Bandung memiliki harga diri tinggi.

Berdasarkan jenis kelamin sebagian besar perawat laki-laki mempunyai harga diri tinggi sebanyak 40 orang $(59,7 \%)$. Hal ini sejalan dengan penelitian yang dilakukan oleh Bickford (2005) yang menyebutkan bahwa laki-laki secara konsisten memiliki harga diri yang lebih tinggi daripada perempuan. Menurut Sumarsongko (2016) terdapat faktor-faktor yang memengaruhi perkembangan harga diri dimana salah satunya adalah perbedaan jenis kelamin.

Berdasarkan usia, perawat pada usia 20-40 tahun memiliki harga diri yang tinggi sebanyak 120 orang $(52,9 \%)$ tetapi jumlah ini tidak terlalu berbeda jauh dengan perawat yang mempunyai harga diri rendah pada kelompok usia tersebut yaitu 107 orang $(47,1 \%)$. Pada kelompok usia tersebut dimana secara perkembangan psikologisnya 
akan menjadi lebih matang dan bijaksana, lebih kreatif dan produktif sehingga akan terjadi peningkatan harga diri dimana harga diri tersebut semakin meningkat seiring dengan pertambahan usia dimulai dari remaja akhir hingga dewasa awal secara signifikan (Bickford, 2005). Perbedaan yang tidak terlalu jauh antara kelompok yang tinggi dan rendah dapat karena oleh adanya faktor-faktor yang mempengaruhi perkembangan harga diri seperti lingkungan keluarga, lingkungan sosial, faktor psikologis dan jenis kelamin (Koentjoro, 1989 dalam Sumarsongko, 2016).

Berdasarkan status pernikahan, perawat yang belum menikah memiliki harga diri rendah sebanyak 37 orang $(56,1 \%)$. Hal ini menurut analisis penulis karena dukungan sosial dari keluarga terutama pasangan hidup dapat meningkatkan harga diri dari seseorang dimana pasangan hidup memiliki fungsi sebagai supporting dalam berbagai hal misalnya emosi, problem solving, keuangan, maupun pengasuhan.

Berdasarkan masa kerja, masa kerja $<2$ tahun memiliki harga diri rendah sebanyak 38 orang $(59,4 \%)$. Di RSUD Kota Bandung perawat baru akan melalui masa orientasi selama 1 tahun dimana perawat tersebut setiap 3 bulan sekali pindah ruangan untuk berorientasi. Hal ini sesuai dengan teori McElroy, Morrow, \& Wardlow (1999) yang menyatakan bahwa pada tahap ini pekerja masih dalam tahap belajar mengenai pekerjaannya, beradaptasi dengan organisasi dan pekerjaannya.

Dari hasil penelitian diketahui bahwa 90 orang perempuan memiliki konflik peran yang tinggi sebagai stresor kerja. Menurut analisis penulis hal ini terjadi karena perawat perempuan yang bekerja di rumah sakit memiliki beberapa peran dalam waktu bersamaan. Sebagai perawat yang senantiasa harus menyelesaikan semua pekerjaan dengan baik dan tepat pada waktunya, sebagai ibu rumah tangga, sebagai istri, dll. Gibson, dkk (2012) menyatakan bahwa wanita mempunyai dua peran yaitu sebagai wanita karir sekaligus ibu rumah tangga. Stressor kerja lebih akan lebih tinggi karena berbagai macam peran yang dijalaninya sebagai seorang ibu, istri, pekerja.

Konflik peran tinggi juga sebagian besar terjadi pada laki-laki sebanyak 39 orang $(58,2 \%)$. Hal ini menurut penulis karena laki-laki cenderung untuk bekerja berbeda dengan kebiasaannya. Hal ini sejalan dengan Luthans (2011) yang menyatakan bahwa konflik peran terjadi ketika pekerja berharap untuk bekerja berbeda dengan kebiasaan yang dilakukan kebanyakan orang atau dituntut untuk melakukan pekerjaan yang bertolak belakang dengan kepribadiannya. Misalnya saat penempatan pegawai di ruangan bukan berdasarkan minat perawat yang bersangkutan melainkan berdasarkan ruangan mana yang membutuhkan tambahan perawat, di samping itu sistem rotasi pegawai belum berjalan dengan maksimal dimana rotasi pegawai belum dilakukan secara berkala.

Jika dilihat dari segi usia, 123 orang yang berusia 20-40 tahun memiliki konflik peran yang tinggi. Hal ini didukung oleh Teori Kleinman (El-Hameid, dkk, 2018) yang menyebutkan bahwa perawat mempunyai risiko mengalami konflik peran cenderung pada perawat yang lebih muda dalam usia.

Perawat yang belum menikah stresor kerja dari konflik perannya tinggi sebanyak 43 orang $(65,2 \%)$. Hal ini menurut Prihatini (2007) bahwa perawat yang telah menikah mampu mengontrol emosinya dalam menghadapi berbagai persoalan baik persoalan internal dan eksternal, sehingga perawat yang telah menikah tidak mudah stress dibandingkan dengan perawat yang belum menikah.

Dilihat dari tingkat pendidikan, perawat 
yang memiliki konflik peran tinggi sebagian besar pada perawat dengan pendidikan S1 Ners. Konflik peran tinggi sebagian besar terjadi pada perawat yang bekerja di ICU yakni 12 orang (63,2\%). Hal ini terjadi karena di ICU, perawat harus menghadapi pasien yang kritis. Di samping tuntutan pemenuhan kebutuhan dari pasien dan keluarga, pemenuhan kebutuhan profesi lain menambah besar konflik kerja yang dirasakan.

Berdasarkan jenis kelamin baik laki-laki maupun perempuan mempunyai ketidakjelasan peran yang tinggi yang menjadikan stresor dalam bekerja. Hal ini sesuai dengan El-Hameid, dkk (2018) yang menyebutkan bahwa tidak ada perbedaan yang signifikan dalam ketidakjelasan peran yang dialami oleh laki-laki dan perempuan

Kelompok usia 20-40 tahun mempunyai ketidakjelasan peran tinggi dimana 153 orang $(67,4 \%)$ menjadikan ketidakjelasan peran sebagai stresor dalam bekerja. Hal ini sesuai dengan penelitian El-Hameid, dkk (2018) bahwa tingginya ketidakjelasan peran pada kelompok usia muda mungkin karena perawat pada usia muda memiliki informasi yang lebih rendah tentang tugas dan tanggung jawab mereka, tidak memiliki banyak pengalaman, mereka tidak mampu merencanakan pekerjaan mereka dan mereka cenderung puas dengan pekerjaan mereka ketika peran didefinisikan dengan jelas.

Status pernikahan baik menikah maupun belum menikah memiliki konflik peran tinggi dimana 108 orang yang sudah menikah dan 49 orang yang belum menikah menjadikan stresor konflik peran dalam bekerja. Tetapi penelitian lain menyebutkan bahwa perawat yang sudah menikah cenderung memiliki ketidakjelasan peran tinggi karena adanya beberapa peran perawat yang sudah menikah yang menyebabkan kebingungan (El-Hameid, dkk, 2018).
Menurut Marquis dan Huston (2010) penerapan sistem jenjang karir merupakan salah satu solusi yang dapat diterapkan untuk menghindari kebosanan dan indiferensi pekerjaan. Jika jenjang karir perawat profesional berdasarkan kompetensi terlaksana, maka akan berdampak positif terhadap pengelolaan SDM keperawatan secara umum. Adanya grading dan mapping SDM perawat sesuai dengan level kompetensi dalam jenjang karir, dapat dijadikan dasar penyusunan remunerasi/pembagian insentif berdasarkan kompetensi. Penjenjangan karir perawat juga dapat dijadikan landasan dalam proses promosi, mutasi dan rotasi perawat. Sehingga dengan berbagai kejelasan yang akan terjadi setelah dijalankannya jenjang karir perawat, maka kemungkinan akan berpengaruh terhadap kepuasan dan kinerja perawat serta mengurangi stresor kerja (Suroso, 2012).

Ketidakjelasan peran yang tinggi sebagian besar terjadi diakibatkan banyak tumpang tindih pekerjaan antara perawat dengan petugas kesehatan lainnya. Diantaranya masih banyak pekerjaan tenaga kesehatan lain yang dilakukan oleh perawat misalnya menyiapkan obat yang menghabiskan cukup banyak waktu yang seharusnya menjadi tanggung petugas farmasi di beberapa ruangan rawat inap menjadi tugas utama perawat sehingga seringkali waktu perawat dihabiskan di ruang dispensing, masih dilakukannya tindakan hecting oleh perawat di IGD. Selain itu di beberapa ruangan administrasi pasien masih dilakukan oleh perawat. Dengan masih tingginya ketidakjelasan peran ini dapat berdampak pada kualitas asuhan keperawatan yang diberikan oleh perawat.

Konflik dalam kelompok sering terjadi karena seseorang secara terus menerus berinteraksi dengan orang lain, sehingga ditemukan perbedaan-perbedaan. Konflik yang terjadi dapat menyebabkan komunikasi 
menjadi tidak baik, kepuasan kerja rendah dan lebih meningkatkan terjadinya stres kerja (Gibson, dkk, 2012).

Menurut hasil penelitian sebagian besar perawat mempunyai konflik dalam kelompok rendah pada usia 41-60. Hal ini disebabkan pada fase dewasa tengah yaitu usia 4160 secara perkembangan psikologis akan lebih matang dan bijaksana, lebih kreatif dan produktif, menjadi pendidik, pengawas bagi generasi selanjutnya. Bertambahnya usia seseorang maka akan meningkat pula kemampuan membuat keputusan, semakin bijaksana dan akan lebih siap menghadapi stress (Jusnimar, 2012).

Pada masa kerja $<2$ tahun konflik dalam kelompok tinggi hal ini dapat disebabkan pada masa kerja $<2$ tahun ini masih pada tahap sekitar belajar pekerjaannya, orientasi, beradaptasi dengan organisasi dan pekerjaannya sehingga kecenderungan untuk terjadi konflik tinggi.

Pada ruangan hemodialiasis konflik dalam kelompok tinggi sebanyak 7 orang. Hal ini dapat disebabkan berdasarkan hasil penelitian didapatkan perawat hemodialisis memiliki harga diri tinggi dimana ketika seseorang dengan harga diri tinggi seseorang cenderung untuk lebih kuat untuk mengutarakan pendapatnya, tidak peka terhadap kritik sehingga kecenderungan untuk terjadinya perbedaan pendapat dan salah paham tinggi yang akan menyebabkan terjadinya konflik.

Konflik di lingkungan rumah sakit seringkali melibatkan perawat dan mengganggu serta dapat menghambat sistem perawatan kesehatan dalam banyak hal (Akpabio, dkk, 2016). Menurut Barkowski (2015), konflik antar kelompok mempunyai ciri kegagalan untuk berkomunikasi, ketidakpercayan dan fokus pada kepentingan diri sendiri. Upaya untuk mencegah konflik antar kelompok adalah melakukan kontak atau komunikasi, melakukan perdamaian, menerima kesepa- katan bersama dan menjalankannya serta melakukan evaluasi.

Pada status pernikahan belum menikah konflik antar kelompok tinggi sebanyak 38 orang $(57,6 \%)$. Hal ini menurut analisis penulis karena seseorang yang belum menikah dukungan dari pasangan hidup belum ada dimana pasangan hidup memiliki fungsi sebagai supporting dalam berbagai hal misalnya emosi, problem solving, keuangan, maupun pengasuhan.

Untuk unit kerja didapatkan hasil bahwa IGD mempunyai konflik antar kelompok tinggi hal ini menurut penulis disebabkan IGD berhubungan langsung dengan seluruh ruangan dimana sering terjadi kesalahpahaman ketika mengantarkan pasien ke ruangan-ruangan dimana setiap kelompok baik IGD atau ruangan-ruangan merasa telah melakukan hal yang benar. Selain itu penyebab konflik antar kelompok menurut Agung (2011) salah satunya adalah stereotype. Stereotype terhadap IGD yang kurang bagus pada salah satu perawat akan membuat seluruh perawat ikut terbawa. Hal ini yang kecenderungan untuk menjadikan stresor perawat dalam kerja.

\section{SIMPULAN}

Tingginya ketidakjelasan peran pada perawat di RSUD Kota Bandung dapat disebabkan oleh kurangnya kejelasan informasi tentang tupoksi sebagai seorang perawat, masih banyaknya pekerjaanpekerjaan yang dilakukan oleh perawat di luar tupoksi dari perawat itu sendiri seperti masih dilakukannya tindakan hecting di IGD oleh perawat, masih melakukan tugas administrasi ketika pasien pulang dan sistem jenjang karir yang belum diterapkan.

Disarankan menjadi data dasar dan sebagai pertimbangan bagi pihak manajemen rumah sakit khususnya bidang perawatan dalam upaya menentukan kebijakan terkait dengan manajemen stres kerja yang 
efektif.

Hasil dari penelitian ini diharapkan dapat dijadikan sebagai bahan pertimbangan dalam menentukan kebijakan terkait manajemen stres kerja bagi perawat sehingga dapat meningkatkan kualitas hidup perawat yang pada akhirnya dapat meningkatkan pelayanan kesehatan di Rumah Sakit.

Keterbatasan penelitian ini, tidak dirancang dari awal untuk membuat prediksi multivariate terhadap variabel dependen, tapi lebih berorintasi pada hubungan antar 2 variabel.

\section{DAFTAR PUSTAKA}

Agung, M. (2011). Konflik antar kelompok: Perspektif psikologi sosial. (Skripsi) Fakultas Psikologi UIN Riau, Indonesia.

Akpabio, I. I., John, M. E., Akpan, M. I., Akpabio, F. F., \& Uyanah, D. A. (2016). Work-related conflict and nurses' role performance in a tertiary hospital in Southsouth Nigeria. Journal of Nursing Education and Practice, 6(2): 106.

Bickford, M. (2005). Stress in the Workplace: A General Overview of the Causes, the Effects, and the Solutions. Canadian Mental Health Association Newfoundland and Labrador Division, 8(1): 1-3.

Borkowski, N. (2015). Organizational Behavior in Health Care. (Alih bahasa: Devi Yulianti). Jakarta: Penerbit Buku Kedokteran EGC. (Buku Asli diterbitkan tahun 2011).

El-Hameid, E. A. A., Mahfouz, E. M., Abood, S. A., \& Mohamed, F. R. (2018). Effect of role conflict and role ambiguity on nurses' performance at Minia and Suzan Mubarak University Hospitals. (Thesis). Faculty of Nursing Assiut University.
Fennell, M. (2016). Overcoming low selfesteem: A self-help guide using cognitive behavioural techniques. Hachette UK.

Gibson, J, Ivansevich J, Donnely R Konopaske D. (2012). Organizations Behavior Structure, fourteenth edition. New York: McGraw Hill Company.

Global Worksforce. (2012). Heath workforce statistic. Retrieved from: http://www. who.int/hrh/statistics/hwfstats/en/

Indrawan, R. (2009). Pegaruh konflik peran terhadap stres kerja dengan ketidakpastian Dan kepuasan kerja sebagai variabel mediasi (Skripsi). FE Universitas Sebelas Maret, Solo, Indonesia.

Ismafiaty. (2009). Hubungan antara strategi koping dan karakteristik perawat dengan stres kerja di ruang perawatan intensif Rumah Sakit Dustira Cimahi. Jurnal Kesehatan Kartika, 3(2).

Jusnimar (2012). Gambaran tingkat stres kerja perawat ICU di Rumah Sakit Kanker Dharmais. (Skripsi). Fakultas IImu Keperawatan, Universitas Indonesia, Jakarta, Indonesia.

Lee, I., \& Wang, H. H. (2002). Perceived occupational stress and related factors in public health nurses. The Journal of Nursing Research: JNR, 10(4): 253-260.

Lee, J. S., Joo, E. J., \& Choi, K. S. (2013). Perceived stress and self-esteem mediate the effects of work-related stress on depression. Stress and Health, 29(1): 75-81.

Lumintang, J. (2015). Dinamika Konflik Dalam Organisasi. Jurnal Acta Diurna, 4(2).

Luthans, F. (2011). Organizational behavior, Twelfth Edition. McGraw-Hill Higher 
Education.

Mangkunegara, A. A. P. (2000). Manajemen sumber daya manusia perusahaan. Bandung: Remaja Rosdakarya.

Marquis, B. L., \& Huston, C. J. (2010). Leadeship roles and management functions in nursing: Theory and application. Edisi keempat. (Alih bahasa: Widyawati dan Handayani). Jakarta: Penerbit Buku Kedokteran EGC.

McElroy, J. C., Morrow, P. C., \& Wardlow, T. R. (1999). A career stage analysis of police officer work commitment. Journal of Criminal Justice, 27(6): 507-516.

Milutinović, D., Golubović, B., Brkić, N., \& Prokeš, B. (2012). Professional stress and health among critical care nurses in Serbia. Archives of Industrial Hygiene and Toxicology, 63(2),:171-180.

Mulyono, F. (2010). Penanganan stres terkait pekerjaan. Jurnal Administrasi Bisnis, 6(2).

National Institute for Occupational Safety and Health (NIOSH). (1999). Stress at work. Cincinnati: DHHS Publication.

National Safety Council. (2004). Stress management. (Alih bahasa: Palupi Widyastuti). Jakarta: Penerbit Kedokteran EGC. (Buku asli diterbitkan tahun 1994).

Nurvia, L., \& Safitri, R. M. (2009). Hubungan antara harga diri dengan burnout pada karyawan bidang pemasaran. Jurnal Psikologi, 6(1): 1-8.

Porter, S. (1992). Women in a women's job: The gendered experience of nurses. Sociology of Health \& IIIness, 14(4): 510-527.

Pramadi, A., \& Lasmono, H. K. (2003). Koping stres pada etnis Bali, Jawa, dan Sunda. Indonesian Psycho- logical Journal, 4(17): 327-340.

Prihatini, L.D. (2007). Analisis hubungan beban kerja dengan stres kerja di tiap ruang rawat inap RSUD Sidikalang (Tesis). Pascasarjana Universitas Sumatera Utara. Medan, Indonesia.

Retnoningsih, T.A. (2000). Faktor-faktor yang berhubungan dengan perilaku perawat dalam penerapan standar asuhan keperawatan di RSUD Dr. Moewardi Surakarta (Skripsi). Universitas Diponegoro, Jawa Tengah, Indonesia.

Rivera-Torres, P., Araque-Padilla, R., \& Montero-Simó, M. (2013). Job stress across gender: the importance of emotional and intellectual demands and social support in women. International journal of Environmental Research and Public Health, 10(1): 375-389.

Setyawan, N. F. B. (2016). Hubungan antara harga diri dengan kinerja pada perawat rumah sakit PKU Muhammadiyah Yogyakarta. Jurnal Sosio Humaniora, 6(1).

SIMRS. (2016). Data pasien rawat inap dan rawat jalan RSUD Kota Bandung. Tidak dipublikasikan.

Somantri, I. (2006). Hubungan persepsi perawat pelaksana tentang gaya kepemimpinan dan tipe kepribadian kepala ruangan dengan kepuasan kerja: Studi di rumah sakit TNI AU tk II" Dr. Salamun" tahun 2006 (Disertasi). FIK-UI, Jakarta, Indonesia.

Sumarsongko, S. (2016). Hubungan antara harga diri dengan perilaku prososial pada satpam PT Danliris Surakarta (Disertasi). Universitas Muhammadiyah Surakarta, Solo, Indonesia.

Suroso, J. (2012). Penataan sistem jenjang 
karir berdasar kompetensi untuk meningkatkan kepuasan kerja dan kinerja perawat di rumah sakit. Eksplanasi, 6(2).

Tankha, G. (2006). A comparative study of role stress in government and private hospital nurses. Journal of Health Management, 8(1): 11-22.

Triwijayanti, R., Dwiantoro, L., \& Warsito, B. E. (2016). Analisis karakteristik individu terhadap kejenuhan perawat. Journal of Nursing and Health $(J N H), 2(1)$.

Undang-undang Republik Indonesia No.
13 Tahun 2003. Retrieved from: https://www.ilo.org/dyn/natlex/ docs/ELECTRONIC/64764/71554/ F1102622842/IDN64764.pdf

Yusuaki, S., Chiba, S., \& Eiji, Y. (2012). Job stress among nurses in Japan. Applied Nursing Research, 25(1): 60-64. 